Vol. 19 (2010): 294-301.

\title{
The effect of calpastatin polymorphism and its interaction with RYRI genotypes on carcass and meat quality of crossbred pigs
}

\author{
Artur Rybarczyk ${ }^{1 *}$, Marek Kmieć ${ }^{2}$, Roman Szaruga ${ }^{1}$, Filip Napierała ${ }^{2}$ and Arkadiusz Terman ${ }^{2}$ \\ ${ }^{1}$ Department of Livestock Product Evaluation, West Pomeranian University of Technology, \\ Doktora Judyma 24 st., 71-466, Szczecin, Poland \\ ${ }^{2}$ Department of Genetics and Animal Breeding, West Pomeranian University of Technology, \\ Doktora Judyma 6 st., 71-466, Szczecin, Poland \\ *e-mail: Artur.Rybarczyk@zut.edu.pl
}

\begin{abstract}
The aim of the study was to establish the relationship between a calpastatin gene (CAST) polymorphism, the ryanodine receptor gene $(R Y R I)$ polymorphism and carcass/meat quality traits in crossbred pigs. No significant differences in the analyzed pigs were found between genotypes $C C$ and $C T$ at the locus $R Y R I$ and $C D$ and $D D$ at the locus $C A S T / M s p \mathrm{I}$ in terms of carcass and meat quality. However, a significant association of the CAST/ApaLI polymorphism with carcass quality and meat marbling were observed. The carcasses of $A B$ pigs had significantly higher carcass percentage of lean meat, thinner backfat and thicker muscle, as well as lower meat marbling, as compared with the $B B$ pigs. Furthermore, interactions $C A S T / M s p I \times R Y R I$ and $C A S T / A p a \mathrm{LI} \times R Y R 1$ were found significant in relation to all the studied carcass traits. The results presented here imply that the CAST gene recognized with ApaLI may be considered as important in terms of the way it affects porcine carcass quality traits. Moreover, the research has revealed a relationship between $C A S T$ and RYRI genotypes as regards formation of carcass traits in pigs. Follow-up studies, however, should be carried out on larger populations representing all possible $C A S T$ genotypes.
\end{abstract}

Key-words: pigs, CAST gene, RYRl gene, carcass quality, meat quality 
Vol. 19(2010): 294-301.

\section{Introduction}

Intensive efforts on improvement of swine percentage of lean meat with use of Pietrain pigs resulted in a number of issues, especially those linked to a high frequency of the stress syndrome gene $\left(R Y R I^{\mathrm{T}}\right)$ observed in this breed, which is associated with occurrence of pale, soft, and exudative (PSE) meat (Fiedler et al. 2001). Moreover, research shows, despite belonging to very different breeds, pigs of the same genotype for the RYR1 gene not only do exhibit a considerable variability in carcass lean content, but also provide meat of varying quality. This may be an effect of other genes that possibly affect both carcass traits and meat quality, modifying the effect of the RYRI (Koćwin-Podsiadła and Kurył 2003).

Calpastatin (CAST) is the endogenous inhibitor involved in regulation of calpain activity in muscle cells. Activity of calpains and calpastatin relies on appropriate concentration of calcium ions in the cell (Murachi 1989). Moreover, calpastatin activity is strongly correlated with muscle growth rate, proteolytic processes, and immediate post mortem changes in the muscle (Goll et al. 1998), which affects many quality traits of the meat (Koćwin-Podsiadła et al. 2003; Melody et al. 2004).

The calpastatin gene has been mapped near the centromere of SSC 2 in the region q2.1-q2.4. The calpastatin molecule consists of domain L, coded by exons 2 to 8 , and four repetitive domains, each of which is coded by exons 9-14 (Stearns et al. 2005). Polymorphisms in the calpastatin gene $(C A S T)$, identified in the intron with 3 restriction enzymes, Hinfl, MspI, and RsaI, were first reported by Ernst et al. (1998). Ciobanu et al. (2004), on the other hand, identified a CAST gene polymorphism at domains L, 1, and 4, recognized using ApaLI, Hpy188I, and PvuII enzymes. Chromosome 2 may be associated with the QTL related to tenderness and shear force because the QTL affiliated with the traits were relatively close in position and shared similar effects (Kurył et al. 2003; Ciobanu et al. 2004). The QTL associated with fat percent was within the same marker inter- val as the QTL related to shear force, suggesting pleiotropic or linked QTL (Malek et al. 2001). Koćwin-Podsiadła et al. (2003) and Krzęcio et al. (2004) demonstrated that a number of meat quality traits significantly depended on the animal's genotype at the locus CAST. The authors state that such correlation can be used in swine selection for better carcass and meat quality. In our studies, on the same cross pigs, in which to identify calpastatin gene (CAST) polymorphism were used restriction enzymes Hinfl and Hpy188I, was found significant association between calpastatin gene (CAST/Hinfl) and meat quality traits (Rybarczyk et al. 2010).

The aim of the study was to find a possible relationship between variants of the calpastatin gene (CAST/MspI and CAST/ApaLI), the ryanodine receptor gene $(R Y R l)$ and carcass/meat quality traits in crossbred pigs sired by Pietrain boars.

\section{Material and methods}

\section{Material}

The experiment was carried out on 125 pigs (76 gilts and 49 barrows) from a pig farm located in Mecklemburg-Vorpommern (Germany). The study comprised offspring from crossing German Landrace $\times$ German Large White and also Leicoma $\times$ German Large White sows with Pietrain boars, kept under similar environmental conditions and fed with a balanced feed-mix ad libitum. All subjects destined for the experiment were conveyed in one group to the "Agryf" Meat Plant in Szczecin (Poland) in the evening after 4 hours transportation from a distance of $250 \mathrm{~km}$, and slaughtered on the next day in the morning.

\section{Slaughter value}

After animal $\mathrm{CO}_{2}$ stunning during the slaughter, blood was collected for identification of CAST and 
Rybarczyk, A. et al. Effects of CAST and RYRl genotypes on carcass and meat quality

$R Y R 1$ genotypes. Subsequently, carcass percentage of lean meat was measured, hot carcass weight, as well as the thickness of the longissimus dorsi (LD) muscle and back fat between the $3 \mathrm{rd}$ and 4 th rib, $7 \mathrm{~cm}$ from the line of carcass partition into the left-hand side of the carcass half, by means of an optic-needle CGM apparatus (Sydel, France). Mean percentage of lean meat amounted to 55.39 \pm 0.40 and hot carcass weight to $87.75 \pm 0.55 \mathrm{~kg}$ (mean value and standard error).

\section{Meat quality and basic meat chemical composition}

Two hours after slaughter during carcass cooling, electric conductivity $\left(\mathrm{EC}_{2}\right)$ was measured in the longissimus dorsi muscle, between the 4 th and 5 th lumbar vertebrae of the right-hand side of the carcass half using an LF-Star MATTHÄUS conductometer. After 24 hours of carcass cooling, meat samples from the longissimus dorsi muscle were collected from the $1^{\text {st }}$ to- $4^{\text {th }}$ lumbar vertebrae section (longgisimus lumborum) of the right-hand side of the carcass half. 24 hours from the slaughter, meat $\mathrm{pH}_{24}$ value (Elmetron CP-311 $\mathrm{pH}$-meter) and the volume of drip loss from the muscle tissue were determined according to Honikel (1987).

Within 48 hours after slaughter, minced meat samples were measured for $\mathrm{pH}$ in water solution, and meat colour traits, i.e. L* (lightness), a* (redness) and $b^{*}$ (yellowness), were established by means of a HunterLab Mini Scan XE Plus 45/0 with light illuminant D65 and observer $10^{\circ}$ (CIE 1976). Meat water-holding capacity (WHC) was determined according to Grau and Hamm (1952) as modified by Pohja and Niinivaara (1957), as well as thermal drip from a difference of meat sample weight before and after heating in a water bath at $85^{\circ} \mathrm{C}$ for 10 minutes. Water-soluble protein content was determined by Kotik method (1974). Marbling (the degree of intramuscular fatness) was determined by a trained 5 person team of panellists, using a 1-5 point scale (1 point - slight muscle fatness; 5 points - strong muscle fatness). The basic meat chemical composition, i.e. total protein, fat, ash and dry matter (AOAC 2003), was estimated.

\section{Genotyping}

Genomic DNA was extracted from blood using a Master Pure kit (Epicentre Technologies). Genotypes $R Y R 1, C A S T / M s p \mathrm{I}$ and CAST/ApaLI were identified by PCR/RFLP method according to Fujii et al. (1991), Ernst et al. (1998) and Ciobanu et al. (2004), respectively.

\section{Statistical analysis}

A statistical analysis was performed to compare carcass and meat quality traits and basic chemical composition of meat between pigs of different CAST and RYR I genotypes, using the least squares method of the GLM procedure (Statistica 8.0 PL) according to the following linear model:

$Y_{i j k l}=\mu+a_{i}+b_{j}+c_{k}+b c_{j k}+\beta\left(x_{i j k l}-\bar{x}\right)+e_{i j k l}$ where:

$Y_{i j k l}$ - trait measured,

$\mu$ - the overall mean,

$a_{i}$ - the effect of $\operatorname{sex}(i=1,2)$,

$b_{j}$ - the effect of RYRl genotype $(j=C T, C C)$,

$c_{k}$ - the effect of $C A S T / M s p$ I genotype $(k=C D, D D)$

or $C A S T / A p a \mathrm{LI}$ genotype $(k=A B, B B)$;

$b c_{j k}$ - interaction $(R Y R 1 \times C A S T / M s p \mathrm{I}$ or $C A S T)$ ApaLI genotype),

$\beta$ - linear regression coefficient for hot carcass weight;

$\mathrm{x}_{i j k l}$ - hot carcass weight of $i j k l$-th individual included as covariable;

$\bar{x}$ - mean for hot carcass weight;

$e_{i j k l}$ - the random error. 
Vol. 19(2010): 294-301.

A detailed comparison of mean least squares (LSQ) for the analysed CAST and RYRl genotypes was done using a Tukey's test.

\section{Results}

The frequencies CAST/MspI, CAST/ApaLI, and $R Y R 1$ of alleles and genotypes in Pietrain-sired pigs are presented in Table 1. The significances of association between the genotypes of calpastatin

Table 1. The frequency of CAST and RYRI alleles and genotypes in analysed pigs.

\begin{tabular}{|c|c|c|c|c|c|c|c|c|c|}
\hline \multirow{2}{*}{$(\mathrm{n}=125)$} & \multicolumn{3}{|c|}{$C A S T / M s p \mathrm{I}$} & \multicolumn{3}{|c|}{$C A S T / A p a \mathrm{LI}$} & \multicolumn{3}{|c|}{ RYRI } \\
\hline & $C C$ & $C D$ & $D D$ & $A A$ & $A B$ & $B B$ & $C C$ & $C T$ & $T T$ \\
\hline No. of animals & - & 68 & 57 & - & 95 & 30 & 71 & 54 & - \\
\hline Frequency of alleles & \multicolumn{3}{|c|}{$C=0.27 \quad D=0.73$} & \multicolumn{3}{|c|}{$A=0.38 B=0.62$} & $C=0.78$ & $T=0$ & \\
\hline Frequency of genotypes $(\%)$ & - & 54.4 & 45.6 & - & 76.0 & 24.0 & 56.8 & 43.2 & - \\
\hline
\end{tabular}

Table 2. The LSQ means of analysed traits and relationship between genotypes at the loci CAST/MspI and CAST/ApaLI and RYR1 for carcass and meat quality in pigs.

\begin{tabular}{|c|c|c|c|c|c|c|c|}
\hline Trait & LSQ & SE & $C A S T / M s p \mathrm{I}$ & $C A S T / A p a \mathrm{LI}$ & RYRI & $\begin{array}{l}\text { CAST/MspI } \\
\times R Y R 1\end{array}$ & $\begin{array}{l}\text { CAST/ApaLI } \\
\times R Y R 1\end{array}$ \\
\hline \multicolumn{8}{|l|}{ Slaughter value } \\
\hline Lean meat content $(\%)$ & 55.39 & 0.39 & n.s. & $p=0.011$ & n.s. & $p=0.006$ & $p=0.007$ \\
\hline Backfat thickness (mm) & 14.90 & 0.38 & n.s. & $p=0.026$ & n.s. & $p=0.037$ & $p=0.006$ \\
\hline Muscle thickness (mm) & 56.64 & 0.58 & n.s. & $p=0.035$ & n.s. & $p=0.014$ & $p=0.047$ \\
\hline \multicolumn{8}{|l|}{ Basic chemical composition } \\
\hline Total protein $(\%)$ & 22.40 & 0.06 & n.s. & n.s. & n.s. & n.s. & n.s. \\
\hline Fat $(\%)$ & 2.52 & 0.05 & n.s. & n.s. & n.s. & n.s. & n.s. \\
\hline Ash (\%) & 1.18 & 0.01 & n.s. & n.s. & n.s. & n.s. & n.s. \\
\hline Dry matter $(\%)$ & 26.10 & 0.07 & n.s. & n.s. & n.s. & n.s. & n.s. \\
\hline Marbling (score) & 1.28 & 0.04 & n.s. & $p=0.020$ & n.s. & n.s. & n.s. \\
\hline \multicolumn{8}{|l|}{ Meat quality } \\
\hline $\mathrm{pH}_{24}$ & 5.66 & 0.01 & n.s. & n.s. & n.s. & n.s. & n.s. \\
\hline $\mathrm{pH}_{48}$ & 5.57 & 0.01 & n.s. & n.s. & n.s. & n.s. & n.s. \\
\hline $\mathrm{EC}_{2}(\mathrm{mS} / \mathrm{cm})$ & 3.08 & 0.12 & n.s. & n.s. & n.s. & n.s. & n.s. \\
\hline $\mathrm{L}^{*}$ & 54.74 & 0.30 & n.s. & n.s. & n.s. & n.s. & n.s. \\
\hline$a^{*}$ & 9.33 & 0.11 & n.s. & n.s. & n.s. & n.s. & n.s. \\
\hline$b^{*}$ & 16.81 & 0.12 & n.s. & n.s. & n.s. & n.s. & n.s. \\
\hline Drip loss $(\%)$ & 7.65 & 0.23 & n.s. & n.s. & n.s. & n.s. & n.s. \\
\hline WHC (\% of free water) & 17.42 & 0.44 & n.s. & n.s. & n.s. & n.s. & n.s. \\
\hline Thermal drip (\%) & 25.88 & 0.25 & n.s. & n.s. & n.s. & n.s. & n.s. \\
\hline Water-soluble protein $(\%)$ & 8.22 & 0.08 & n.s. & n.s. & n.s. & n.s. & n.s. \\
\hline
\end{tabular}

n.s. - statistically not significant. 
Rybarczyk, A. et al. Effects of CAST and RYR1 genotypes on carcass and meat quality

(CAST/MspI and CAST/ApaLI), RYRI and carcass and meat quality traits of the pigs are presented in Table 2.

We did not find any significant differences between the genotypes $C C$ and $C T$ of the RYRI in terms of carcass percentage of lean meat, backfat and LD muscle thickness, as well as in meat quality and basic chemical composition determined in the longissimus lumborum muscle.

Significant differences were found in carcass slaughter performance and meat marbling between pigs of genotypes $A B$ and $B B$ at the locus $C A S T /$ $A p a$ LI (Table 3 ). The $A B$ pigs had significantly higher percentage of lean meat, thinner backfat, thicker LD muscle, and lower marbling of the meat as compared with the $B B$ genotype $(p \leq 0.05)$. No significant association, however, was found between the CAST/ApaLI genotype and meat quality traits of the pigs. Moreover, significant $C A S T /$ $A p a \mathrm{LI} \times R Y R I$ interactions were found in terms of carcass quality. Significantly higher percentage of lean meat and thinner backfat $(p \leq 0.01)$, as well as thicker LD muscle ( $p \leq 0.05)$, were found in the $A B / C T, A B / C C$, and $B B / C T$ genotypes in relation to $B B / C C$ pigs (Table 4 ).

No significant effect of the CAST/MspI polymorphism on carcass and meat quality or meat basic chemical composition was observed. Significant $C A S T / M s p \mathrm{I} \times R Y R 1$ interactions, however, were found as regards carcass quality of the pigs.

Table 3. The relationship between genotypes at the CAST/ApaLI locus and carcass quality traits in pigs.

\begin{tabular}{lcc}
\hline Item & $A B$ & $B B$ \\
\hline No. of animals & 95 & 30 \\
Lean meat content (\%) & $55.93^{\mathrm{a}} \pm 0.43$ & $53.70^{\mathrm{b}} \pm 0.91$ \\
Backfat thickness (mm) & $14.46^{\mathrm{a}} \pm 0.40$ & $16.30^{\mathrm{b}} \pm 0.92$ \\
Muscle thickness (mm) & $57.28^{\mathrm{a}} \pm 0.66$ & $54.57^{\mathrm{b}} \pm 1.14$ \\
Marbling (score) & $1.24^{\mathrm{a}} \pm 0.04$ & $1.43^{\mathrm{b}} \pm 0.10$ \\
\hline
\end{tabular}

Results in the table are given as LSQ mean \pm standard error

${ }^{a, b}$ Mean values marked by different small letters differ significantly at $\mathrm{p} \leq 0.05$.

Table 4. Effect of interaction between CAST and RYR1 genotypes and carcass quality traits in pigs.

\begin{tabular}{lcccc}
\hline \multirow{2}{*}{ Item } & \multicolumn{4}{c}{$C A S T / A p a \mathrm{LI}$ and $R Y R 1$ genotypes } \\
\cline { 2 - 5 } & $A B / C T$ & $B B / C T$ & $A B / C C$ & $B B / C C$ \\
\hline No. of animals & 34 & 20 & 61 & 10 \\
Lean meat content (\%) & $56.18^{\mathrm{A}} \pm 0.66$ & $55.28^{\mathrm{A}} \pm 0.81$ & $55.78^{\mathrm{A}} \pm 0.56$ & $50.56^{\mathrm{B}} \pm 1.88$ \\
Backfat thickness (mm) & $13.94^{\mathrm{A}} \pm 0.66$ & $14.80^{\mathrm{A}} \pm 0.81$ & $14.75^{\mathrm{A}} \pm 0.51$ & $19.30^{\mathrm{B}} \pm 1.97$ \\
Muscle thickness (mm) & $56.53^{\mathrm{a}} \pm 0.90$ & $56.40^{\mathrm{a}} \pm 1.32$ & $57.70^{\mathrm{a}} \pm 0.90$ & $50.90^{\mathrm{b}} \pm 1.70$ \\
\hline & & $C A S T / M s p \mathrm{I}$ and $R Y R 1$ genotypes & \\
\cline { 2 - 5 } & $C D / C T$ & $D D / C T$ & $C D / C C$ & $D D / C C$ \\
\hline No. of animals & 31 & 23 & 37 & 34 \\
Lean meat content (\%) & $56.16^{\mathrm{A}} \pm 0.75$ & $55.41^{\mathrm{AB}} \pm 0.65$ & $53.61^{\mathrm{B}} \pm 0.85$ & $56.61^{\mathrm{A}} \pm 0.71$ \\
Backfat thickness (mm) & $14.13^{\mathrm{a}} \pm 0.75$ & $14.43^{\mathrm{ab}} \pm 0.67$ & $16.43^{\mathrm{b}} \pm 0.82$ & $14.26^{\mathrm{ab}} \pm 0.67$ \\
Muscle thickness (mm) & $57.26^{\mathrm{ab}} \pm 1.07$ & $55.43^{\mathrm{ab}} \pm 0.95$ & $54.78^{\mathrm{a}} \pm 1.12$ & $58.88^{\mathrm{b}} \pm 1.22$ \\
\hline
\end{tabular}

Results in the table are given as LSQ mean \pm standard error

${ }^{\mathrm{A}, \mathrm{B}}$ Mean values marked by different capital letters differ significantly at $p \leq 0.01$.

${ }^{\mathrm{a}, \mathrm{b}}$ Mean values marked by different small letters differ significantly at $p \leq 0.05$. 
Vol. 19(2010): 294-301.

The $D D / C C$ and $C D / C T$ pigs had significantly higher percentage of lean meat $(p \leq 0.01)$ and thinner backfat $(p \leq 0.05)$ as compared with the $C D /$ $C C$ genotype. Moreover, $D D / C C$ pigs had a significantly thicker $\mathrm{LD}$ in relation to $C D / C C(p \leq 0.05)$.

\section{Discussion}

The presented study on Pietrain-sired pigs of unknown family structure did not reveal significant differences in carcass or meat quality between $C C$ and $C T$ genotype at the locus RYR1. Results by other authors who studied carcass and meat quality in the same genotypes of pigs with Pietrain genes are not unambiguous. Busk et al. (2000) stated that the carcasses of $C T$ pigs contained more lean and had worse meat quality as compared with the $C C$ pigs. Kusec et al. (2005) did not observe significant differences in butchery value of carcasses between the $C C$ and $C T$ pigs; the authors found, however, that meat quality of heterozygous pigs $(C T)$ was worse. Also Krzęcio et al. (2005) and Kuhn et al. (2005) report poorer quality of meat obtained from $C T$ pigs. On the other hand, Koćwin-Podsiadła et al. (2003) did not find significant differences in meat quality between the discussed $R Y R 1$ genotypes.

The analysis of CAST/MspI genotypes frequency in the studied crossbred pigs sired by Pietrain boars revealed two genotypes, $C D$ and $D D$, which was also reported by Kurył et al. (2003) in pigs obtained from the program TORHYB [Pietrain $\times$ (Polish Landrace $\times$ Polish Large White)] as well as in Polish Landrace pigs. In both the cited report and studies by Ernst et al. (1998), Pietrain pigs were monomorphic at the locus CAST/MspI and were of $D D$ genotype. All three possible genotypes were observed in Yorkshire and Large White pigs (Ernst et al., 1998), as well as in Stamboek (Dutch Large White $\times$ Dutch Landrace) and Złotnicka Spotted (Kurył et al. 2003).

We did not observe significant differences in carcass quality between pigs of $C D$ and $D D$ genotypes at the locus CAST/MspI. Conversely, Kurył et al. (2003) demonstrated a relationship between the
CAST/MspI polymorphism and some carcass quality traits in $R Y R I^{\mathrm{T}}$-free Stamboek hogs. $D D$ pigs had thinner backfat at some measurement points and a larger rib eye area in relation to $C C$ pigs. Also Koćwin-Podsiadła et al. (2004) observed that crossbred, $R Y R I^{\mathrm{T}}$-free fatteners revealed significant effect of association between the CAST/MspI genotype and five out of 19 analyzed carcass traits. The authors report that activity of a given molecular type of calpastatin depends on the muscle, since $B B$-genotype pigs at $C A S T / M s p$ I had a larger ham weight, whereas larger loins were cut from $A A$ pigs.

The analyzed pigs did not show a significant association between the $C A S T / M s p$ I genotype and meat quality as well as basic chemical composition of meat in the longissimus lumborum muscle. Also Koćwin-Podsiadła et al. (2003) and Kurył et al. (2004), who studied crossbreds sired by Duroc $\times$ Pietrain boars, failed to demonstrate a relationship between the $C A S T / M s p$ I genotype and meat quality traits, except for loin efficiency during smoking. Krzęcio et al. (2005), on the other hand, observed significant effects of the CAST/MspI polymorphism on the level of lactic acid in the longissimus lumborum muscle tissue 45 minutes post mortem, index of energy metabolism intensity $\mathrm{R}_{1}$, water holding capacity (WHC), drip loss from muscle tissue at 48 and 96 hours post mortem, as well as meat protein and water content. Moreover, Koćwin-Podsiadła and Kurył (2003) demonstrate that polymorphism at the locus $C A S T / M s p$ I relatively strongly correlates with the incidence of increased drip loss from meat in the group of pigs with the gene RYRI ${ }^{\mathrm{T}}$.

We have demonstrated here a significant association between the CAST/ApaLI genotype and carcass quality traits and meat marbling. Bonforroni's correction revealed a significant linkage between the CAST/ApaLI and percentage of lean meat. It is known that the proteolytic calpain-calpastatin system has its role in the processes of muscle growth and development. Results of experiments show that the calpain system is important for the proper development of the skeletal muscles. An increased rate of skeletal muscles development may be a result of a reduced rate of protein degradation in the muscle, which is associated with a reduced activity of the calpain system resulting mainly from a 
Rybarczyk, A. et al. Effects of CAST and RYRl genotypes on carcass and meat quality

considerable increase in calpastatin activity (Goll et al. 1998). The presented results may indicate that calpastatin as calpains inhibitor may behave differently depending on the genetic variant. Moreover, analysis found significant evidence of QTL on SSC 2 associated with backfat thickness, longissimus muscle area and fat percent (Malek et al. 2001; Stearns at al. 2005).

The analysis of the pigs revealed significant effect of interactions, CAST/ApaLI $\times R Y R I$ and $C A S T / M s p I \times R Y R 1$, in relation to carcass quality traits only, i.e. percentage of lean meat, backfat and LD muscle thickness. Bonforroni's correction revealed significant interactions between $C A S T / M s p \mathrm{I}$ $\times R Y R 1$ in relation to percentage of lean meat and muscle thickness, as well as between CAST/ApaLI $\times R Y R 1$ in relation to percentage of lean meat and backfat thickness. On the other hand, Krzęcio et al. (2005), who studied a group of crossbred pigs, observed a significant effect of interaction between the RYRI and CAST/MspI genotype for muscle tissue acidity 24 hours post mortem and drip loss from the LL tissue 48 hours post mortem. In the studies on crossbred pigs sired by Duroc $\times$ Pietrain boars, an interaction between the CAST/MspI and RYRI genotypes was significant only for loin efficiency during smoking (Koćwin-Podsiadła et al. 2003) and drip loss measured at 48 hours post mortem (Kurył et al. 2004). The authors (Kurył et al. 2004; Krzęcio et al.2005) conclude that the frequency of meat with high drip loss in pigs free of the stress sensibility gene (genotype $C C$ at the locus $R Y R 1$ ), as well as that of normal meat in carriers of the gene (genotype $C T$ at the locus $R Y R l$ ) may be a result of a joint modifying effect of the CAST gene on the post mortem changes in the muscle tissue.

\section{Conclusions}

No significant differences in the analyzed pigs sired by Pietrain boars were found between genotypes $C C$ and $C T$ at the RYRI locus and $C D$ and $D D$ at the $C A S T / M s p$ I locus in terms of carcass and meat quality. However, a significant influence was found of the $C A S T / A p a \mathrm{LI}$ polymorphism on carcass quality and meat marbling. The carcasses of $A B$ pigs had significantly higher percentage of lean meat, thinner backfat, and thicker LD muscle, as well as lower meat marbling, as compared with the $B B$ pigs. Furthermore, interactions $C A S T / M s p \mathrm{I} \times R Y R I$ and $C A S T / A p a \mathrm{LI} \times R Y R 1$ were found significant in relation to all the studied carcass traits, i.e. percentage of lean meat, backfat thickness, and LD thickness.

The results presented here imply that the $C A S T$ gene recognized with $A p a$ LI may be considered as important in terms of the way it affects porcine carcass quality traits. Moreover, research has revealed an association between CAST and RYRI genotypes as regards formation of carcass traits in pigs. Follow-up studies, however, should be carried out on larger populations representing all possible CAST genotypes.

\section{References}

AOAC 2003. Official methods of analysis (17th ed.). Association of Official Analytical Chemists. Gaithersburg, USA.

Busk, H., Karlsson, A. \& Hertel, S.H. 2000. Halothane gene effect on carcass and meat quality by use of Duroc $x \mathrm{Pi}-$ etrain Boars. In: Wenk, C., Fernandez J.A. \& Dupuis, M. (eds.). Quality of meat and fat in pigs as affected by genetics and nutrition. Proceedings of the joint session of the EAAP commissions on pig production, animal genetics and animal nutrition, Zurich, Switzerland. Wageningen Pers. Wageningen, The Netherlands, p. 129-133.

Ciobanu, D.C., Bastiaansen, J.W.M., Lonergan, S.M., Thomsen, H., Dekkers, J.C.M., Plastow, G.S. \& Rothschild, M.F. 2004. New alleles in calpastatin gene are associated with meat quality traits in pigs. Journal of Animal Science 82: 2829-2839.

CIE (Commission International de l'Eclairage) 1976. Colorimetry.: Official Recommendations of the International Commission on Illumination. Publication CIE, 15 (E1.3.1). Bureau Central de la CIE, Paris, France.

Ernst, C.W., Robic, A., Yerle, M., Wang, L. \& Rothschild, M.F. 1998. Mapping of calpastatin and three microsatellites to porcine chromosome 2q2.1-q2.4. Animal Genetics 29: 212-215.

Fiedler, I., Kuhn, G., Hartung, M., Küchenmeister, U., Nürnberg, K., Rehfeldt, C., Huber, K. \& Kłosowska, D. 2001. Effects of the malignant hyperthermia syndrome (MHS) on meat quality, muscle fibre characteristics and metabolic traits of the Longissimus muscle in Pietrain pigs. Archiv Tierzucht, Dummerstorf 44: 203-217.

Fujii, J., Otsu, K., Zorzato, F., De Leon, S., Khana, V.K., Weiler, J.E., Obrien, P.J. \& Maclennan, D.H. 1991. 


\section{AGRICULTURAL AND FOOD SCIENCE}

Vol. 19(2010): 294-301.

Identification of a mutation in porcine ryanodine receptor associated with Malignant Hyperthermia. Science 253: 448-451.

Goll, D.E., Thompson, V.F., Taylor, R.G. \& Ouali, A. 1998. The calpain system and skeletal muscle growth. Canadian Journal of Animal Science 78: 503-512.

Grau R. \& Hamm R. 1952. Eine einfache Methode zur Bestimmung der Wasserbindung in Fleisch. Fleischwirtschaft 4: 295-297.

Honikel, K.O. 1987. pH and water binding of meat. Fleischwirtschaft 67: 1098-1102.

Koćwin-Podsiadła, M. \& Kurył, J. 2003. The effect of interaction between genotypes at loci CAST, RYR1 and RN on pig carcass quality and pork traits - a review. Animal Science Papers and Reports 21 (Suppl. 1): 61-75.

Koćwin-Podsiadła, M., Kurył, J., Krzęcio, E., Antosik, K., Zybert, A. \& Sieczkowska, H. 2004. An association between genotype at the CAST (calpastatin) locus and carcass quality traits in porkers free of RYR $1^{\top}$ allele. Animal Science Papers and Reports 22: 497-505.

Koćwin-Podsiadła, M., Kurył, J., Krzęcio, E., Zybert, A. \& Przybylski, W. 2003. The interaction between calpastatin and RYR1 genes for some pork quality traits. Meat Science 65: 731-735.

Kotik, T. 1974. Zawartość białka w ekstraktach wodnych mięsa jako wskaźnik jego jakości. (Protein content in water extracts of meat as an index of its quality). Roczniki Instytutu Przemysłu Mięsnego 12: 47-52. (in Polish with abstract in English)

Krzęcio, E., Koćwin-Podsiadła, M., Kurył, J., Antosik, K., Zybert, A., Sieczkowska, H., Pospiech, E., Łyczyński, A. \& Grześ, B. 2004. An association between genotype at the CAST locus (calpastatin) and meat quality traits in porkers free of $R Y R 1^{\top}$ allele. Animal Science Papers and Reports 22: 489-496.

Krzęcio, E., Kurył, J., Koćwin-Podsiadła, M. \& Monin, G. 2005. Association of calpastatin (CAST/Mspl) polymorphism with meat quality parameters of fatteners and its interaction with RYR1 genotypes. Journal Animal Breeding and Genetics 122: 251-258.

Kuhn, G., Fiedler, I., Ender, K. \& Mattes, W. 2005. Duroc and Pietrain breedings in comparison. Fleischwirtschaft 85: 92-96.
Kurył, J., Kapelański, W., Pierzchała, M., Grajewska, S. \& Bocian, M. 2003. Preliminary observations on the effect of calpastatin gene (CAST) polymorphism on carcass traits in pigs. Animal Science Papers and Reports 21: 87-95.

Kurył, J., Krzęcio, E., Koćwin-Podsiadła, M. \& Monin, G. 2004. The influence of CAST and RYR1 genes polymorphism and their interactions on selected meat quality parameters in four-breed fatteners. Animal Science Papers and Reports 22: 479-488.

Kusec, G., Baulain, U., Henning, M., Köhler, P. \& Kallweit, E. 2005. Fattening, carcass and meat quality traits of hybrid pigs as influenced by MHS genotype and feeding systems. Archiv Tierzucht Dummerstorf 48: 40-49.

Malek, M., Dekkers, J.C.M., Lee, H.K., Baas, T.J., Prusa, K., Huff-Lonergan, E. \& Rothschild, M.F. 2001. A molecular genome scan analysis to identify chromosomal regions influencing economic traits in the pig. II. Meat and muscle composition. Mammalian Genome 12: 637-645.

Melody, J.L., Lonergan, S.M., Rowe, L.J., Huiatt, T.W., Maye,s M.S. \& Huff-Lonergan, E. 2004. Early post mortem biochemical factors influence tenderness and water-holding capacity of three porcine muscle. Journal of Animal Science 82: 1195-1205.

Murachi, T. 1989. Intracellular regulatory system involving calpain and calpastatin. Biochemistry International 18: 263-294.

Pohja, M.S. \& Niinivaara, F.P. 1957. Die Bestimmung der Wasserbindung des Fleisches mittels der Konstantdrückmethode. Fleischwirtschaft 9: 193-195.

Rybarczyk, A., Kmieć, M., Napierała, F., Natalczyk-Szymkowska, W. 2010. The effect of calpastatin polymorphism (CAST/Hinfl and CAST/Hpy188I) and its interaction with RYR1 genotypes on carcass and pork quality of crossbred pigs. Animal Science Papers and Reports 28: 253-260.

Stearns, T.M., Beever, J.E., Southey, B.R., Ellis, M., McKeith, F.K. \& Rodriguez-Zas, S.L. 2005. Evaluation of approaches to detect quantitative trait loci for growth, carcass, and meat quality on swine chromosomes 2, 6, 13, and 18. I. Univariate outbred F2 and sib-pair analyses. Journal of Animal Science 83: 1481-1493. 